\title{
PENYULUHAN PEMASARAN BENUR UDANG VANAME (LITOPENAEUS VANNAMEI) HASIL PANTI PEMBENIHAN SKALA RUMAH TANGGA (HSRT) DI DUSUN KEMBANGSAMBI DESA PASIRPUTIH BUNGATAN
}

\author{
Musyaffa Rafiqie \\ Universitas Ibrahimy Sukorejo, Indonesia \\ fiq.dewi@gmail.com
}

\begin{abstract}
The purpose of marketing counseling for whiteleg shrimp seeds (Litopenaeus vannamei) from a household scale hatchery (HSRT), Kembangsambi, Pasir Putih, Bungatan was to motivate and to provide information about the marketing of whiteleg shrimp seeds. Activity method which is used to solve the problems mentioned above is marketing counseling for whiteleg shrimp seeds. This activity includes the material for marketing counseling activities, taxonomy of whiteleg shrimp, marketing concept with planning strategy, and marketing mix.

The results of this counseling activity are the farmers will be able to maintain the marketing of whiteleg shrimp seeds, will be able to apply the marketing concept with strategic planning for whiteleg shrimp seeds, and will be able to apply the marketing mix for the marketing of whiteleg shrimp seeds so that it will increase economic growth in the Situbondo Regency and in particularly improve the household economy.
\end{abstract}

Keyword: Penyluhan Pemasaran, Benur Udang, Pembenihan

Vol. 3 No. 1, A pril 2021

Musyaffa Rafiqie| 55 Zurnal Pengabdian Masyarakat 


\section{Pendahuluan}

Universitas Ibrahimy Situbondo, berada dibawah naungan Yayasan Pondok Pesantren Salafiyah Syafiiyah Sukurejo, Situbondo. Universitas Ibrahimy Situbondo dalam melaksanakan tugas Tri Dharma Perguruan Tinggi, pertama kegiatan pendidikan dan pengajaran, kedua penelitian dan ketiga pengabdian kepada masyarakat. Universitas Ibrahimy Situbondo memiliki 7 (tujuh) Fakultas dan satu Fakultas Pascasarjana, dengan jumlah Prodi strata 1/ (S1) sebanyak 22 prodi dan prodi strata 2 (S2) sebanyak 2 prodi.

Kegiatan pengabdrian masyarakat Fakultas Sains dan Tekhnologi (Sainstek) merupakan bagian dari Universitas Ibrahimy Situbondo dalam penyelenggaraan program kegiatan pengabdian kepada masyarakat yang dilakukan oleh Dosen Fakultas Sains dan Tekhnologi (Sainstek) sesuai bidang atau prodi masing-masing guna mewujudkan Visi, Misi dan tujuan Universitas Ibrahimy Situbondo. Dosen Fakultas Sains dan Tekhnologi (Sainstek) melaksanakan kegiatan pengabdian di Panti Pembenihan Ikan/Udang, dengan judul kegiatan adalah “Penyuluhan Pemasaran Benur Udang Vaname ((Litopenaeus vannamei) di Panti Pembenihan Ikan/Udang Skala Rumah Tangga 
(HSRT) Dusun Kembang Sambi Desa Pasirputih, Kecamatan Bungatan.".

Penyuluhan merupakan suatu proses tarnsfer pengetahuan (transfer konwledge) kepada petani ikan/udang. Hal ini disebabkan penyuluhan merupakan sebagai kegiatan penyebaran informasi yang diperlukan oleh petani ikan/udang. Penyebaran informasinya melalui proses pengajaran dan pembelajaran orang dewasa yang berfokus pada kemampuan dalam mengemukakan pendapat/ide dan pengalaman guna merubah perilaku dan mendorong untuk kreatif serta inovatif dalam berkarya. Tujuan penyuluhan pemasaran benur udang vaname ((Litopenaeus vannamei) hasil panti pemebenihan skala rumah tangga (HSRT), Dusun Kembangsambi, Desa Pasirputi, Kecamatan Bungatan adalah untuk memberikan dan menyebarkan informasi tentang pemasaran benur udang vaname ((Litopenaeus vannamei). Pemasaran penyuluhan pemasaran benur udang vaname ((Litopenaeus vannamei) di panti pemebenihan skala rumah tangga (HSRT), Dusun Kembangsambi, Desa Pasirputi, Kecamatan Bungatan dipasarkan ke Pasuruan, Surabaya, Gresik, lamongan, Tuban, Lasem, Demak bahkan ke Kalimantan. Para pembeli tersebut datang ke lokasi panti pemebenihan skala rumah tangga (HSRT). Biasanya para pembeli 
benur udang vaname ((Litopenaeus vannamei) adalah petani ikan/udang tradisional, yang memiliki luas petak tambak seluas 0,1 ha sampai dengan 1 ha. Petani ikan/udang tradisional biasanya, ikan dan udang dalam satu petak tambak atau dikenal dengan multispesies. Ikan dan udang yang dipelihara dalam satu petak tambak adalah ikan bandeng (Chanos chanos) dan udang windu (Monodon bachilus) dan atau udang vaname ((Litopenaeus vannamei). Benur udang vaname ((Litopenaeus vannamei), yang dijual berukuran post larva/Pl

sampai dengan 14).dengan harga perekor Rp 12,- sampai dengan Rp15,.Kegiatan pemasaran yang dilakukan oleh pembenih ikan/udang benur udang vaname ((Litopenaeus vannamei) hanya menunggu para pembeli.

Hal ini terungkap hasil wawancara dengan petani ikan/udang adalah sebagai berikut:

Saya sudah menjalankan usaha pembenihan ikan/udang \pm 22 tahun. Di awal saya menjalankan usaha pembenihan ikan/udang, saya membenihkan udang windu sebab saat itu, permintaan benur udang windu cukup baik. Saat permintaan benur windu mengalami penurunan karena banyak benur windu mengalami terserang penyakit, maka saya beralih pada pembenihan udang vaname ((Litopenaeus 
vannamei). Isu yang berkembang saat itu bahwa benur udang vaname ((Litopenaeus vannamei,.tahan terhadap serangan penyakit. Hingga saat ini, saya masih tetap bertahan dengan kegiatan pembenihan udang vaname ((Litopenaeus vannamei). Dan saya memasarkan dengan cara memasang plang ada "Benur vaname" hanya itu yang saya lakukan (T.W 01.05/09/2020).

Petani pembenih ikan/udang menjalankan usahanya sudah cukup lama dan mereka dalam menjalankan usahanya sudah menerapkan, kreatifitas dalam menjalankan usahanya, hal ini dibuktikan dengan saat permintaan benur windu turun mereka beralih atau berusaha dengan membenihkan benur udang vaname ((Litopenaeus vannamei). Namun dari sisi cara memasarkan mereka masih perlu diberikan penyuluhan tentang pemasaran yakni pada: Taxonomy udang vaname ((Litopenaeus vannamei), menerapkan konsep pemasaran dengan perencanaan strategis benur udang vaname ((Litopenaeus vannamei), dan bauran pemasaran atau marketing mix usaha pemasaran benur udang vaname ((Litopenaeus vannamei). Materi tersebut diberikan dengan pertimbangan bahwa: pertama petani pembenih ikan/udang masih belum pernah mendapatkan penyuluhan tentang materi tersebut, kedua materi tersebut merupakan suatu materi yang sering dihadapi oleh 
petani pembenih ikan/udang, ketiga diharapkan dengan diberikan materi tersebut akan memberikan motivasi untuk kreatif dan mengembangkan inovasi dalam pemasaran benur udang vaname ((Litopenaeus vanname).

Dari masalah tersebut diatas, maka perlu diadakan kegiatan penyuluhan pemasaran benur udang vaname ((Litopenaeus vannamei), bagi petani ikan/udang.

Permasalahan yang dihadapi dalam pemasaran benur udang vaname ((Litopenaeus vannamei) adalah sebagai berikut:

Permasalahannya meliputi:

1. Permasalahan menerapkan konsep pemasaran dengan perencanaan strategis benur udang vaname ((Litopenaeus vannamei), dan bauran pemasaran atau marketing mix usaha pemasaran benur udang vaname ((Litopenaeus vannamei).

2. Permasalahan benur bauran pemasaran atau marketing mix usaha udang vaname ((Litopenaeus vannamei)

Dari permasalahan tersebut diatas, maka pemecahan masalahnya dengan cara kegiatan penyuluhan pemasaran benur udang vaname ((Litopenaeus vannamei) hasil panti pemebenihan skala rumah tangga (HSRT), Dusun Kembangsambi, Desa Pasirputih, Kecamatan Bungatan 
adalah sebagai berikut:.

Tujuan penyuluhan pemasaran benur udang vaname ((Litopenaeus vannamei) adalah:

1. Penyuluhan pemasaran benur udang vaname ((Litopenaeus vannamei) hasil panti pemebenihan skala rumah tangga (HSRT), Dusun Kembangsambi, Desa Pasirputi, Kecamatan Bungatan untuk memberikan dan menyebarkan informasi tentang pemasaran benur udang vaname ((Litopenaeus vannamei), sehingga diharapkan setelah diadakan penyuluhan pemasaran benur udang vaname ((Litopenaeus vannamei), maka petani pembenih ikan/udang termotivasi, kreatif, imajinatif, dan inovatif dalam melaksanakan kegiatan pemasaran benur udang vaname ((Litopenaeus vannamei), dengan demikian akan meningkatkan ekonomi keluarga.

2. Sasaran kegiatan penyuluhan pemasaran benur udang vaname ((Litopenaeus vannamei). Terwujudnya atau terciptanya satu unit pembenih petani ikan/udang pemasar benur udang vaname ((Litopenaeus vannamei), panti pemebenihan skala rumah tangga (HSRT) untuk meningkatkan dan membangkitkan perekonomian 
daerah, khususnya peningkatkan ekonomi keluarga petani

ikan/udang benur udang vaname ((Litopenaeus vannamei).

\section{Keterkaitan dengan fungsi}

Untuk melaksanakan dan mensukseskan kegiatan penyuluhan pemasaran benur udang vaname ((Litopenaeus vannamei), pada panti pemebenihan skala rumah tangga (HSRT) maka dibutuhkan kerjasama dengan pihak yang lain sebagai pemegang pemangku kebijakan, seperti Dinas Kelautan dan Perikanan Kabupaten Situbondo. Diharapkan instansi tersebut memberikan dukungan dapat berupa tenaga ahkli (penyuluh perikanan dan petugas tekhnis lapangan). Selama kegiatan penyuluhan pemasaran benur udang vaname ((Litopenaeus vannamei), sudah banyak dibantu oleh instansi tersebut diatas, guna mensukseskan kegiatan penyuluhan pemasaran benur udang vaname ((Litopenaeus vannamei). Bentuk bantuan dan dukungan yang di berikan adalah mengirim penyuluh perikanan dan petugas tekhnis lapangan.

\section{Manfaat Kegiatan}

Manfaat kegiatan penyuluhan pemasaran benur udang vaname ((Litopenaeus vannamei), panti pemebenihan skala rumah tangga (HSRT) dan dibekali teori tentang Taxonomy udang vaname ((Litopenaeus vannamei), menerapkan konsep pemasaran dengan 
perencanaan strategis benur udang vaname ((Litopenaeus vannamei), dan bauran pemasaran atau marketing mix usaha pemasaran benur udang vaname ((Litopenaeus vannamei). sehingga petani ikan/udang mengalami peningkatan pengetahuan dan keterampilannya guna diterapkan dan dimplementasikan.

\section{Metode}

\section{Menerapkan Konsep Pemasaran Dengan Perencanaan Strategis}

Menerapkan konsep pemasaran dengan perencanaan strategis merupakan suatu proses kegiatan yang dilaksanakan oleh manajemen, dengan mempertahankan dan mengembangkan, melalui penerepan keahlian dan sumber daya organisasi sesuai dengan peluang pasar yang terus berubah guna menciptakan atau mewujudkan tujuan organisasi/perusahaan. Menurut Agustina Shinta (2011) mengatakan bahwa tujuan penerapan konsep pemasaran melalui perencanaan strategis adalah untuk membentuk dan menyempurnakan usaha serta produk perusahaan sehingga memenuhi target laba dan pertumbuhan.3

Kegiatan menerapkan konsep pemasaran dengan perencanaan strategis, diawali dengan analisa lingkungan organisasi/perusahaan eksternal dan internal. Analisa lingkungan organisasi/perusahaan eksternal yang dianalisa tentang peluang dan ancaman, sedangkan 
analisa lingkungan organisasi/perusahaan internal yang dianalisa adalah kekuatan dan kelemahan. Dari kedua faktor tersebut, setelah dianalisa, selanjutnya membuat formula sasaran, setelah membuat formula strategi dan kemudian membuat formula program yang selanjutnya diimplementasikan, hasil implementasi di evaluasi apa sudah sesuai dengan visi, misi dan tujuan organisasi/perusahaan.

Untuk menganalisa lingkungan organisasi/perusahaan eksternal dan internal dapat digunakan analisa SWOT. Kegiatan analisa SWOT membutuhkan tenaga dan pikiran yang optimal, artinya pihak manajemen organisasi/perusahaan harus bekerja keras dan mengoptimalkan fungsi manajemen.

Kesalahan dalam melakukan analisa SWOT maka akan berdampak pada organisasi/perusahaan salah dalam mengambil keputusan strategis dan target laba serta pertumbuhan tidak tercapai. Kesalahan dalam melakukan analisa SWOT, disebabkan karena kesalahan dalam menentukan faktor formula sasaran, formula strategi, formula program sehingga salah dalam penerapan/implementasi.

Terkadang kegagalan suatu bisnis atau organisasi/perusahaan bukan tidak memiliki suatu kekuatan pada di masing-masing bagian, akan tetapi dapat juga disebabkan karena dimasing-masing bagian tidak 
bekerja dengan optimal. Di suatu organisasi/perusahaan setiap staff akan berpikir bahwa kegagalan disebabkan karena dibagian produksi tidak menghasilkan produksi yang berkualitas, dibagian pemasaran akan mengatakan bahwa di bagian penjualan kurang optimal dalam memberikan pelayanan pada konsumen.

Berikut ini digambarkan pada gambar 1 tentang proses perencanaan strategis adalah sebagai berikut:

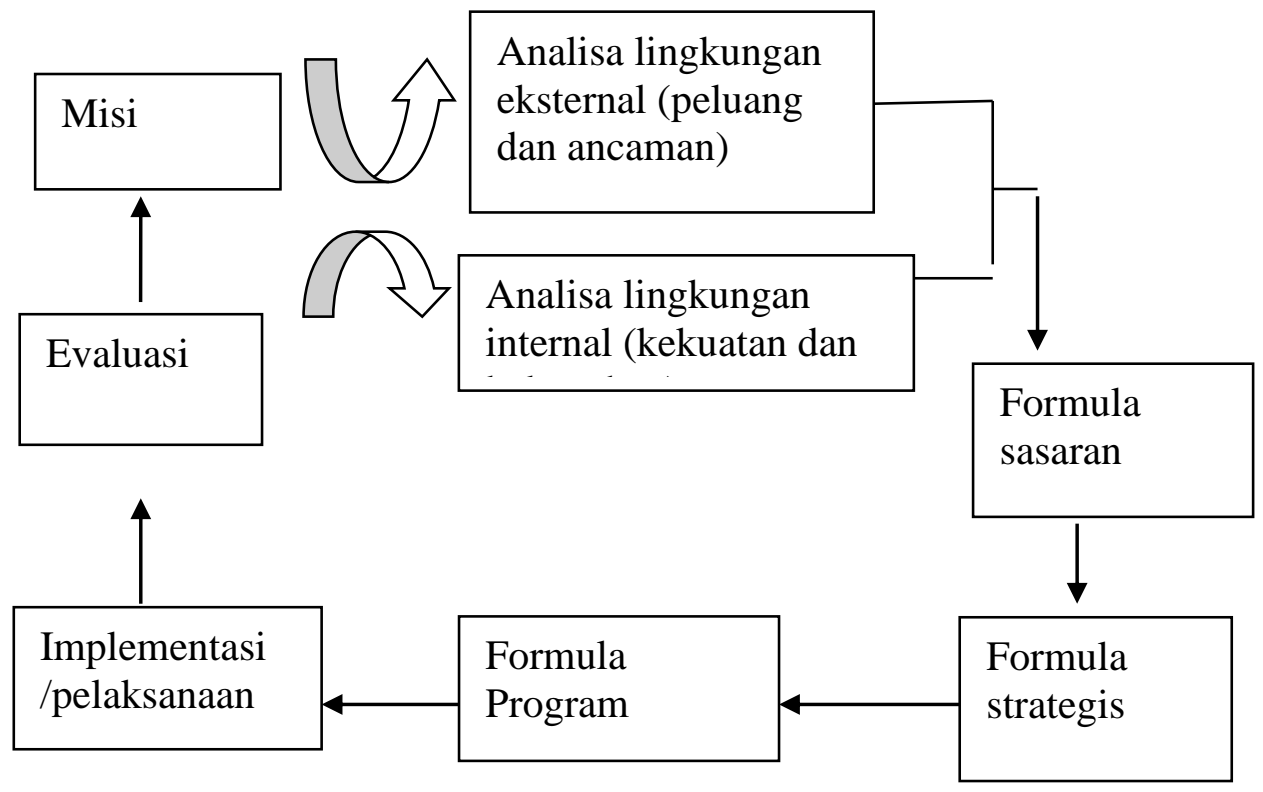

Sumber : Agustina Shanti, 2011 Manajemen Pemasaran

Lingkungan eksternal adalah sebagai berikut:: ekonomi, 
demografi, geografi, sosial budaya, tekhnologi, pemasok, instansi pemerintah (Pemerintah Pusat regulasi kebijakan dan Pemerintah Daerah Tingkat I dan II), kreditor (Koperasi/Bank), ketenaga kerjaan (ketersediaan tenaga kerja terampil), dan konsumen. Sedangkan faktor internal meliputi: pelayanan pada konsumen, produksi, sumberdaya manusia, keuangan dan Role and Development (R and D), harga, dan kemudahan mendapatkan informasi.

\section{Bauran pemasaran /Marketing mix}

Menurut Kotler dan Armstrong (2009) mengatakan bahwa Marketing Mix is the set of marketing tools that the firmuses to pursue its marketing objectives in the target market yakni bauran pemasaran adalah seperangkat alat pemasaran yang digunakan perusahaan untuk mengejar tujuan pemasarannya di pasar sasaran. Pengertian alat adalah berhubungan dengan (1) harga (price), (2) produk, (3) tempat (place), dan (4) promosi. Keempat variable tersebut merupakan satu kesatuan yang tidak terpisahkan dalam kegiatan pemasaran. Dengan demikian, penting untuk diketahui oleh seorang pemimpin/manajer organisasi/perusahaa untuk menciptakan atau mewujudkan tujuan pemasaran. ${ }^{5}$

Usaha benur udang vaname ((Litopenaeus vannamei) hasil panti 
pemebenihan skala rumah tangga (HSRT), Dusun Kembangsambi, Desa Pasirputih, Kecamatan Bungatan, dapat juga menerapkan pendekatan strategis pemasraran yang diarahkan pada kemampuan pasar guna mewujudkan dan meningkatkan kualitas pelayanan dengan membuat standar kualitas produk benur yang berkualitas. Dengan cara mempertahankan kualitas benur, harga yang bersaing, serta meningkatkan promosi.

Keempat variable yang berhubungan dengan bauran pemasaran dapat digambarkan atau diilustrasikan dalam gambar 2 dibawah ini:

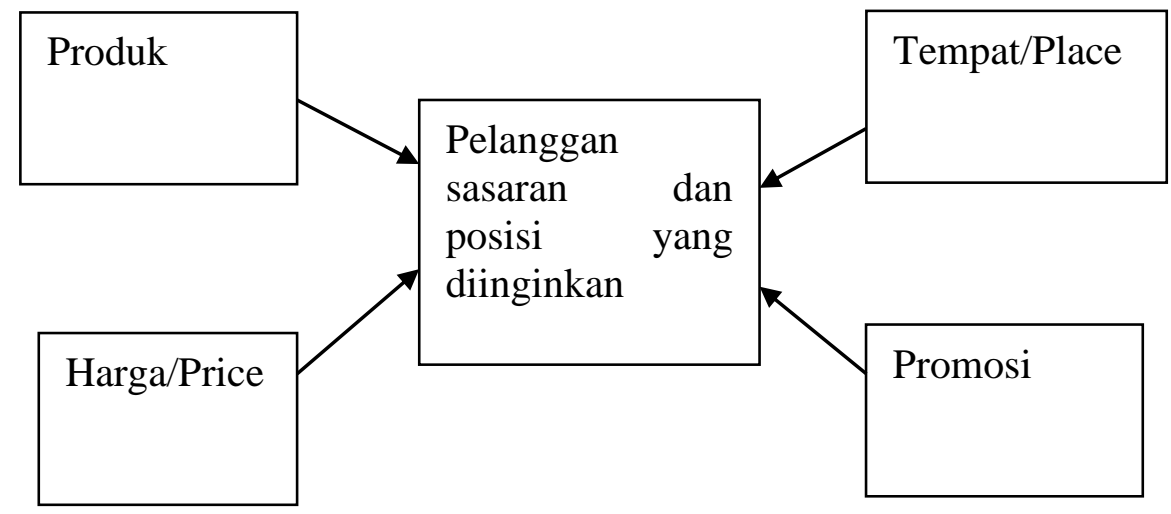

Gambar 2, keempat variable tertuju atau mengarah pada pelanggan sasaran dan posisi yang diinginkan oleh organisasi/perusahaan. Produk merupakan sesuatu yang dihasilkan oleh organisasi/perusahaan, untuk dikonsumsi dan digunakan sesuai 
dengan kebutuhan dari pelanggan. Menurut Kotler (2001) mengatakan bahwa produk adalah segala sesuatu yang dapat ditawarkan ke pasar untuk diperhatikan, diperoleh, digunakan, atau dikonsumsi yang dapat memenuhi keinginan atau kebutuhan.6 Dari pengertian tersebut, maka produk adalah sesuatu yang dihasilkan oleh organisasi/perusahaan untuk diperhatikan, diperoleh, digunakan, atau dikonsumsi guna memenuhi sesuai kebutuhan yang dibutuhkan oleh pelanggan.

Unsur produk merupakan unsur yang disesuaikan dengan tingkat kebutuhan dari konsumen. Unsur produk primer, sekunder, tersier dan lain sebagainya. Menurut Christopher Lovelock, et al (2010) mengatakan bahwa unsur produk nilainya atau pemanfaatannya sangat tergantung pada konsumen, yang memperhatikan tentang manfaat produk, efektivitas pemakaian dan memiliki nilai tambah.7

Untuk menentukan harga maka ada beberapa prinsip yang perlu diperhatikan oleh perusahaan. Menurut Kotler (2001) mengatakan ada 6 enam prinsip dalam menentukan harga yakni: pertama memperhatikan tujuan penetapan harga, menentukan tingkat permintaan, perkiraan biaya, menganalisa harga yang ditetapkan dan produk yang ditawarkan pesaing, pemilihan metode penetapan harga, serta menentukan harga akhir, kedua memaksimumkan penerimaan, dan memaksimumkan 
penguasaan pasar atau kemungkinan lainnya, ketiga pengusaha/pemasar produk harus memahami respon dari suatu permintaan pasar, keempat berbagai jenis biaya harus dipertimbangkan dalam menetapkan harga, termasuk di dalamnya adalah biaya langsung dan tidak langsung, biaya tetap dan biaya variabel, serta biaya-biaya yang lain, kelima harga pesaing akan mempengaruhi tingkat permintaan yang ditawarkan, untuk itu harga pesaing harus turut dipertimbangkan dalam proses penetapan harga, dan keenam cara menetapkan harga yang ada mencakup seluruh biaya produksi, sasaran perolehan, nilai yang dapat diterima, faktor psikologis, diskon harga, serta harga promosi. 8

Menurut Lupiyoadi R, dan Hamdani A. ada 8 (delapan) faktor dalam menentukan harga yakni (1) elastisitas permintaan (2) struktur biaya, (3)persaingan, (4) positioning dari usaha yang ditawarkan, (5) sasaran yang ingin dicapai organisasi/perusahaan, (6) perputaran usaha (7) sumber daya yang digunakan dan (8) kondisi ekonomi.9

Lokasi (place), berhubungan dengan tempat untuk memudahkan bertemunya antara produsen dan konsumen. Menurut Kotler (2009) mengatakan bahwa lokasi (place) saluran distribusi terdiri atas seperangkat lembaga yang melakukan segala kegiatan (fungsi) yang 
digunakan untuk menyalurkan produk dan status pemiliknya dari produsen ke konsumen. Oleh karena itu, manajemen harus dapat memilih saluran distribusi dengan memperhatikan kemungkinan lingkungan penjualan sekarang dan kemudian hari. Dengan demikian, Kotler meninjau dari mudahnya saluran distribusi, artinya bahwa tempat/lokasi usaha berada pada tempat/lokasi didukung dengan kebutuhan pemasok yang dibutuhkan untuk berproduksi. Untuk itu, perlu diperhatikan tentang lokasi dari kegiatan usaha.

Promosi merupakan suatu kegiatan mengkomunikasikan produk yang dihasilkan kepada konsumen untuk konsumen tertarik mengunakan produk tersebut. Menurut Kotler (2001) mengatakan bahwa promosi suatu usaha mempengaruhi/membujuk pada pelanggan/konsumen yang potensial untuk mengunakan produk yang dihasilkan.10

Dalam promosi ada 4 faktor yang perlu diperhatikan oleh perusahaan, yakni (1) menyampaikan pesan yang disampaikan dengan cara persuasiv, yakni suatu pesan yang disampaikan dapat mempengaruhi si penerima pesan. Menurut Kotler (2009) mengatakan bahwa pesan persuasif merupakan sarana komunikasi yang berusaha menginformasikan, membujuk, dan mengingatkan konsumen baik 
secara langsung maupun tidak langsung.11

(2) sales promotion yakni suatu kegiatan atau usaha untuk membantu guna mendapatkan konsumen yang bersedia membeli produk dan mengunakan produknya, (3) public relation J.Frank , , mengatakan : “Public Relations is the continuing process by which management endeavors to obtain goodwill and understanding of its customers, its employees and the public at large, inwardly through self-analysis and correction, outwardly through all means of expression." Hubungan Masyarakat adalah proses berkelanjutan di mana manajemen berusaha untuk mendapatkan itikad baik dan pemahaman tentang pelanggannya, karyawannya, dan publik pada umumnya, secara batin melalui analisis dan koreksi diri, secara lahiriah melalui semua cara ekspresi.12 (4) personal selling merupakan komunikasi langsung antara penjual dan calon pelanggan untuk memperkenalkan suatu produk kepada calon pelanggan dan membentuk pemahaman pelanggan terhadap produk sehingga mereka kemudian akan mencoba dan membelinya.

\section{Pelaksanaan Kegiatan}

Pelaksanaan kegiatan yang meliputi: bentuk kegiatan, output dan outcome kegiatan, gambaran kegiatan, keberlanjutan kegiatan, dan rekomendasi kegiatan penyuluhan.

Vol. 3 No. 1, A pril 2021 


\section{Bentuk kegiatan}

Kegiatan pengabdian masyarakat di penyuluhan pemasaran benur udang vaname ((Litopenaeus vannamei) hasil panti pemebenihan skala rumah tangga (HSRT), Dusun Kembangsambi, Desa Pasirputih, Kecamatan Bungatan, dilaksanakan pada bulan SDN 4 Ngenep dan SMPN 3 Karangploso Satu Atap Desa Ngenep Kecamatan Karangploso dilaksanakan pada bulan oktober bertempat di panti pemebenihan skala rumah tangga (HSRT), Dusun Kembangsambi, Desa Pasirputih, Kecamatan Bungatan. Kegiatan yang dilaksanakan adalah penyuluhan pemasaran benur udang vaname ((Litopenaeus vannamei).

Tahapan kegiatan penyuluhan pemasaran benur udang vaname ((Litopenaeus vannamei) hasil panti pemebenihan skala rumah tangga (HSRT) adalah sebagai berikut:

\section{Persiapan kegiatan}

1. Survey penentuan peserta penyuluhan

2. Setelah mendapatkan lokasi peserta penyuluhan, kemudian menentukan tentang persiapan dan penentuan tanggal pelaksanaan;

3. Menyelesaikan administrasi terkait pelaksanaan kegiatan penyuluhan 
4. Mempersiapkan sarana yang dibutuhkan dalam kegiatan penyuluhan

\section{Pelaksanaan kegiatan penyuluhan}

1. Pembukaan acara penyuluhan

2. Penyampaian materi penyuluhan

3. Sesi diskusi atau tanya jawab dengan peserta penyuluhan

\section{Penutupan}

\section{Output dan outcome kegiatan penyuluhan}

Output kegiatan penyuluhan pemasaran benur udang vaname ((Litopenaeus vannamei) hasil panti pemebenihan skala rumah tangga (HSRT), Dusun Kembangsambi, Desa Pasirputih, Kecamatan Bungatan adalah sebagai berikut:

1. Petani pembenih diberikan materi tentang teori Taxonomy udang vaname ((Litopenaeus vannamei), menerapkan konsep pemasaran dengan perencanaan strategis benur udang vaname ((Litopenaeus vannamei), dan bauran pemasaran atau marketing mix usaha pemasaran benur udang vaname ((Litopenaeus vannamei). 
2. Dari penjelasan tentang materi yang sudah disampaikan ke petani pembenih dan diakhir penyampaian materi dilaksanakan evaluasi, dihasilkan pertanyaan dari pembenih adalah sebagi berikut:

a. Apa yang dimaksud dengan konsep dan bauran pemasaran perencanaan strategis benur udang vaname ((Litopenaeus vannamei)?

b. Apa yang harus diketahui dalam konsep dan bauran pemasaran perencanaan strategis benur udang vaname ((Litopenaeus vannamei)?

c. Bagaimana mengimplementasikan konsep dan bauran pemasaran dalam kegiatan pembenihan udang vaname ((Litopenaeus vannamei)?

\section{Outcome kegiatan penyuluhan}

Outcome kegiatan penyuluhan pemasaran benur udang vaname ((Litopenaeus vannamei). Terwujudnya atau terciptanya satu unit pembenih petani ikan/udang pemasar benur udang vaname ((Litopenaeus vannamei), panti pemebenihan skala rumah tangga (HSRT) untuk meningkatkan dan membangkitkan perekonomian daerah, khususnya peningkatkan ekonomi keluarga petani ikan/udang benur udang vaname ((Litopenaeus vannamei) 
kegiatan penyuluhan pemasaran benur udang vaname ((Litopenaeus vannamei), panti pemebenihan skala rumah tangga (HSRT) sehingga petani ikan/udang mengalami peningkatan pengetahuan dan keterampilannya guna diterapkan dan dimplementasikan.

Universitas Ibrahimy pada Fakultas Sains dan Tekhnologi, khususnya Program Studi Budidaya Perikanan sebagai lembaga pendidikan memiliki suatu kepedulian pada masyarakat, khususnya pada masyarakat pembenih ikan/udang guna mendapatkan informasi tentang pemasaran, khususnya pemasaran dalam bidang perikanan yakni, pembenihan benur udang vaname ((Litopenaeus vannamei), panti pemebenihan skala rumah tangga (HSRT) serta untuk meningkatkan pengetahuan dan keterampilan sehingga dapat diberdayakan dalam rangka terwujudnya atau terciptanya peningkatan dan kesejahteraan pembenih udang vaname ((Litopenaeus vannamei), di panti pemebenihan skala rumah tangga (HSRT).

\section{Gambaran kegiatan}

Gambaran kegiatan penyuluhan pemasaran benur udang vaname ((Litopenaeus vannamei) hasil panti pemebenihan skala rumah tangga (HSRT), Dusun Kembangsambi, Desa Pasirputih, Kecamatan Bungatan, 
secara umum berlangsung dengan aman, nyaman serta sukses. Petani ikan/udang pembenih dengan seksama mengikuti kegiatan penyuluhan pemasaran. Dan peserta penyuluhan adalah petani ikan/udang pembenih udang vaname ((Litopenaeus vannamei). Tempat yang digunakan untuk kegiatan penyuluhan adalah depan pintu masuk bak pembenihan.

Kegiatan penyuluhan diawali perbincangan dengan petani pembenih ikan/udang, sebab penyuluh sebelumnya sudah mengenal dengan baik pada petani ikan/udang. Penyuluh bertanya tentang pemasaran, yakni kemana pemasarannya, apakah memberikan pelayanan dengan senyum ramah atau berdiskusi dulu dengan calon pelanggan/pembeli. Sebab terkadang ada calon pembeli benur ada yang masih uji coba dalam berbisnis udang vaname ((Litopenaeus vannamei). Apakah sudah pernah disuluhkan tentang materi pemasaran, apakah sudah membaca tentang materi pemasaran, mengapa diberikan materi pemasaran.

Kegiatan penyuluhan dilaksanakan seperti yang terjadwal dalam kegiatan pelaksanaan penyuluhan, di tanggal 24 oktober 2020 materi taxonomy udang vaname ((Litopenaeus vannamei) selama 30 menit, dan materi pemasaran pelaksanaan penyuluhan, di tanggal 31 oktober 2020 dipaparkan selama 45 menit, selama pemaparan materi 
berlangsung dengan aman, nyaman dan belum ada kendala. Setelah dipaparkan atau dijelaskan materi, peserta diberikan kesempatan untuk mengajukan pertanyaan. Peserta bertanya bagaimana menerapkan konsep pemasaran perencanaan strategis pada benur udang vaname ((Litopenaeus vannamei) dan bagaimana menerapkan konsep bauran pemasaran/marketing mix pada benur udang vaname ((Litopenaeus vannamei) khususnya tentang penetuan harga.

Lingkungan eksternal pembenih petani ikan/udang benur udang vaname (Litopenaeus vannamei) Dusun Kembangsambi, Desa Pasirputih, Kecamatan Bungatan terdapat atas 10 faktor adalah sebagai berikut:

a. Faktor ekonomi, yang dimaksud adalah tempat atau keberadaan usaha pembenih petani ikan/udang, benur udang vaname ((Litopenaeus vannamei), \pm ada 9 pembenih. Setiap pembenih memilki 7 bak sampai dengan 12 bak, ukuran bak 8 ton sampai dengan 15 ton. Peralatan pembenihan lengkap dalam setiap unit pembenihan.

b. Faktor demografi, dengan jumlah penduduk sebanyak 50194, jenis kelamin laki-laki sebanyak 25037 jiwa dan perempuan sebanyak 
25157 jiwa. Dengan tingkat pendidikan masih ditemukan penduduk yang belum tamat pada jenjang pendidikan sekolah dasar.

c. Faktor geografi Wilayah geografi Dusun Kembang Sambi Desa Bungatan, Kecamatan Bungatan berada pada posisi antara $7^{\circ} 35^{\prime}-$ $7^{\circ} 44^{\prime}$ Lintang Selatan dan $113^{\circ} 30^{\prime}-114^{\circ} 42^{\prime}$ Bujur Timur. Batas wilayah disebelah Timur berbatasan dengan Desa Kendit, disebelah Barat berbatasan dengan Desa Mlandingan, di sebelah Utara berbatasan dengan Pantai (Selat Madura) dan sebelah Selatan Bukit Bungatan.

d. Faktor sosial budaya, dihubungkan dengan hasil usaha yang dihasilkan oleh masyarakat Dusun Kembang Sambi Desa Bungatan, Kecamatan Bungatan yakni pembenihan udang/ikan. Dari kegiatan tersebut, sejak adanya kegiatan dimaksud Dusun Kembang Sambi Desa Bungatan, Kecamatan Bungatan dikenal dibeberapa daerah dalam propinsi maupun antar propinsi.

e. Faktor tekhnologi kegiatan usaha pembenihan udang vaname ((Litopenaeus vannamei), masih belum memanfaatkan tekhnologi komputer dalam kegiatan usahanya. Petani pembenih ikan/udang mencatat hasil produksi dan hasil pemasaran dalam satu buku, bahkan terkadang belum dicatat dengan baik. 
f. Faktor pemasok, yang dimaksud pemasok nauplie. Nauplie adalah telur dari udang yang dipasok dari pembenih sendiri atau bekerjasama dengan PT pembenihan yang ada disekitar usaha kegiatan pembenihan. Pemasok telur sendiri biasanya petani pembenih memiliki bak yang berukuran 14 ton (memiliki bak induk). Untuk pemasok nauplie cukup tersedia disepanjang siklus pembenihan.

g. Faktor konsumen berasal dari luar daerah seperti: Pasuruan, Surabaya, Gresik, lamongan, Tuban, Lasem, Demak bahkan ke Kalimantan.

h. Faktor Institusi Pemerintah. Pemerintah dalam hal ini Kementerian Kelautan dan Perikanan, Pemerintah Propinsi Jawa Timur dan Pemerintah Kabupaten mendukung kegiatan usaha pembenihan tersebut. Dukungan yang diberikan oleh Pemerintah berupa bantuan tekhnis dan non tekhnis.

i. Faktor kreditor, didukung oleh pihak kedua dalam hal ini pihak Koperasi dan perbankan.

j. Faktor ketersediaan tenaga kerja, untuk ketersediaan tenaga kerja tercukupi sebab kegiatan usaha pembenih petani ikan/udang, benur udang vaname ((Litopenaeus vannamei), Dusun Kembang Sambi 
Desa Bungatan, Kecamatan Bungatan. Menurut sejarahnya bahwa masyarakat Dusun Kembang Sambi Desa Bungatan, Kecamatan Bungatan, sejak tahun 1980 an sudah melakukan kegiatan usaha pembenihan ikan/udang karena didukung berdirinya Panti pembenihan air Payau milik Kementerian Kelautan dan Perikanan dan Dinas Kelautan dan Perikanan Propinsi Jawa Timur.

Lingkungan internal pembenih petani ikan/udang benur udang vaname (Litopenaeus vannamei) Dusun Kembangsambi, Desa Pasirputih, Kecamatan Bungatan adalah sebagai berikut:

Pertama pemberian pelayanan pada konsumen. Aspek pemberian pelayanan pada pelanggan (customer) yang dilakukan oleh pembenih petani ikan/udang benur udang vaname ((Litopenaeus vannamei), masih sebatas memperlihatkan produk benur udang vaname ((Litopenaeus vannamei) Kedua produksi kemampuan petani pembenih ikan/udang memiliki tingkat produksi cukup besar. Setiap unit pembenih ikan/udang memiliki 6 sampai 8 bak pembenihan masingmasing bak dengan berukuran 10 ton dapat ditebar benur sebanyak 1 juta benur, sedangkan ukuran bak pembenih berukuran ada yang 14 ton, maka jika 14 ton dapat ditebar sebanyak 1,5 juta atau 1,7 juta benur. Dengan demikian, memiliki prospek yang cukup baik apabila dikelola 
dan didukung oleh kebijakan pemerintah dan pasar yang stabil. Ketiga sumberdaya manusia yang dimiliki oleh petani pembenih ikan/udang cukup andal dan baik sebab mereka sudah cukup lama berkecimpung dalam kegiatan pembenihan udang. Keempat modal yang dimiliki masih terbatas, sebab modal yang digunakan didapat dari koperasi atau perbankkan namun modal usaha yang diberikan oleh pihak koperasi atau perbankkan adalah sebesar 20 sampai dengan $30 \%$ dari modal operasionalnya. Kelima budaya organisasi cukup baik. Indikator yang digunakan adalah komunikasi antara pegawai/pekerja terjalin dengan baik.

\section{Keberlanjutan kegiatan penyuluhan}

Kegiatan penyuluhan pemasaran benur udang vaname ((Litopenaeus vannamei) hasil panti pemebenihan skala rumah tangga (HSRT), Dusun Kembangsambi, Desa Pasirputih, Kecamatan Bungatan, diharapkan akan dilaksanakan secara berkesinambungan mengingat petani ikan/udang yang ada di Dusun Kembangsambi, Desa Pasirputih, Kecamatan Bungatan, masih jarang dilakukan penyuluhan materi pemasaran

\section{Rekomendasi kegiatan}

Dari hasil kegiatan penyuluhan pemasaran benur udang vaname 
((Litopenaeus vannamei) hasil panti pemebenihan skala rumah tangga (HSRT), Dusun Kembangsambi, Desa Pasirputih, Kecamatan Bungatan,

1. Kegiatan penyuluhan tentang pemasaran sebaiknya dilakukan secara kontinyu, berkesinambungan, dan berkelanjutan serta untuk meberikan dan menyebarkan informasi tentang pemasaran benur udang vaname ((Litopenaeus vannamei) serta memotivasi dan kreatif dalam pemasaran sehingga pada akhirnya dapat mempertahankan usahanya.

2. Perlu diadakan kerjasama dengan instansi terkait.

\section{Jadwal kegiatan penyuluhan}

\begin{tabular}{|l|l|l|}
\hline Uraian kegiatan & Hari /tgl & Penyuluh \\
\hline Survey lokasi lokasi & Sabtu 24/10/2020 & $\begin{array}{l}\text { Musyaffa } \\
\text { Rafiqie }\end{array}$ \\
\hline $\begin{array}{l}\text { Berangkat ke 20/10/2020 } \\
\text { penyuluhan }\end{array}$ & & Musyaffa \\
\hline Kegiatan penyuluhan & Rafiqie \\
\hline $\begin{array}{l}\text { Materi I Taxonomy udang } \\
\text { vaname (Litopenaeus vannamei) }\end{array}$ & Jam 09.00 s/d 09.20 & \\
\hline
\end{tabular}

Vol. 3 No. 1, A p ri 12021 


\begin{tabular}{|l|l|l|}
\hline Materi II & Sabtu 31/10/2020 & Musyaffa \\
menerapkan konsep pemasaran & Jam $09.30 \mathrm{~s} / \mathrm{d} 10.10$ & Rafiqie \\
dengan perencanaan strategis & & \\
benur udang vaname & & \\
$\left(\begin{array}{l}\text { (Litopenaeus vannamei), dan } \\
\text { bauran pemasaran atau }\end{array}\right.$ & & \\
marketing mix usaha pemasaran & & \\
benur udang vaname & & \\
$(($ Litopenaeus vannamei) & & \\
& & \\
\hline Tanya jawab/diskusi & & \\
\end{tabular}

\section{Penutup}

\section{Kesimpulan}

Penyuluhan pemasaran benur udang vaname ((Litopenaeus vannamei) yang dilaksanakan di panti pemebenihan skala rumah tangga (HSRT), Dusun Kembangsambi, Desa Pasirputih, Kecamatan Bungatan, sudah terlaksana dengan baik. 
Penyuluhan pemasaran benur udang vaname ((Litopenaeus vannamei) yang dilaksanakan di panti pemebenihan skala rumah tangga (HSRT), Dusun Kembangsambi, Desa Pasirputih, Kecamatan Bungatan, direspon oleh petani pembenih ikan/udang dengan antusias dan baik.

Lingkungan eksternal pembenih petani ikan/udang benur udang vaname (Litopenaeus vannamei) Dusun Kembangsambi, Desa Pasirputih, Kecamatan Bungatan terdapat atas 10 faktor. Dan lingkungan internal pembenih petani ikan/udang benur udang vaname (Litopenaeus vannamei) Dusun Kembangsambi, Desa Pasirputih, Kecamatan Bungatan ada lima (5) faktor.

\section{Saran}

Penyuluhan pemasaran benur udang vaname ((Litopenaeus vannamei) yang dilaksanakan di panti pemebenihan skala rumah tangga (HSRT), Dusun Kembangsambi, Desa Pasirputih, Kecamatan Bungatan, dapat dilaksanakan di panti pemebenihan skala rumah tangga (HSRT) di lokasi yang lain, untuk penyebaran informasi tentang pemasaran benur udang vaname ((Litopenaeus vannamei) 


\section{Daftar pustaka}

A.T Forbest et al, A Review of the commercial shalow water penaed prawn resourch of South Africa, Marine and Estuarine Research, 2005.

Christopher Lovelock, dkk., Pemasaran Jasa Manusia, Teknologi, Strategi, Jilid 1, Edisi Ketujuh, Jakarta: Erlangga, 2010.

David, Strategic Mranagement Jakarta : Salemba Empat, 2006. :https://www.researchgate.net/profile/Hans_Nauwynck/publication/301 497351/figure/fig1/AS:651937737347082@1532445477816/Externalmorphology-of-penaeid-shrimp-Corteel-2013.png

Frank Jefkins, Public Relations, Airlangga, Jakarta.

Philip Kotler dan Kevin Lane Keller, Manajemen Pemasaran, Terjemahan : Benyamin Molan, Edisi 13, Jakarta: PT. Indeks. 2009. Philip Kotler, Manajemen Pemasaran di Indonesia,Terjemah Herujati Purwoko, Jakarta: Salemba Empat, 2001.

Rambat Lupiyoadi, dan A. Hamdani, Manajemen Pemasaran Jasa, Jakarta: Salemba Empat, 2009. 
JURNAL

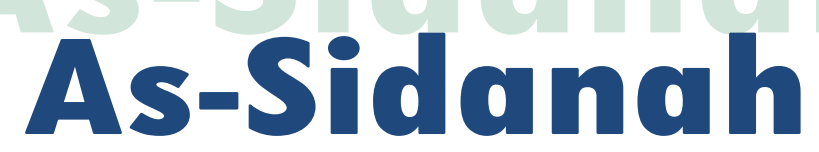

Vol. 03 No. 1, April 2021

Vol. 3 No. 1, A pril 2021

Musyaffa Rafiqie| 86 qurnal Pengabdian Masyarakat 